Mini Review

\title{
Diverse application and future prospects for commercial cultivation of microalgae species: A review
}

\author{
Nishesh Sharma, Ajay Singh, Felicia Lalremruati, Vanlalmalsawmi \& Rohit Sharma \\ Uttaranchal College of Applied and Life Sciences (UCALS), Uttaranchal University, Dehradun, India
}

\section{Article history}

Received: 25 May 2019

Accepted: 31 July 2019

Published: 01 October 2019

\section{Publisher}

Horizon e-Publishing Group

\section{*Correspondence}

Nishesh Sharma

$\triangle$ nishesh21@gmail.com

\begin{abstract}
Industrial revolutions, advancements in health care, pharmaceuticals, transportation can be attributed to advancements made in the field of science and technology. Environment and natural resources has paid a heavy cost for most of industrial development. Rapid depletion of nonrenewable sources of energy eventually leading towards the energy crisis, direct or indirect release of industrial effluents into soil and natural water bodies, global warming are among major consequences of industrialization. Ever since these environmental concerns have been recognized substantial studies have been conducted to minimize, control pollution and restore environment and natural resources. Among several measures cultivation of algae on large scale stands out to be a multipurpose solution. Inherent potential of microalgae species to accumulate lipids makes algae an efficient source of biofuel. Beside this ability of algae to detoxify polluted water and industrial effluent support utilization of algae for environment management and restoration. Efficient $\mathrm{CO}_{2}$ fixation, ability to tolerate wide range of environmental conditions, minimal nutritional requirements further support commercial cultivation of algal species to achieve their widespread application. However, efforts are required to develop large scale cultivation protocols (beyond the range of photobioreactors) so as to achieve practical applicability of algae and their products. Alongwith, cultivation protocols there is simultaneous need of either selection of naturally occurring high yielding strains / species or genetic improvement. Standardization of optimum cultivation conditions along with harvesting procedure is equally important.
\end{abstract}

Keywords: Microalgae; Biofuel; Bioremediation; Bioplastic

Citation: Sharma N, Singh A, Lalremruati F, Vanlalmalsawmi, Sharma R. Diverse application and future prospects for commercial cultivation of microalgae species: A review. Plant Science Today 2019;6(4):427-432. https://doi.org/10.14719/pst.2019.6.4.581

Copyright: ( ) Sharma et al (2019). This is an open-access article distributed under the terms of the Creative Commons Attribution License, which permits unrestricted use, distribution, and reproduction in any medium, provided the original author and source are credited (https://creativecommons.org/licenses/by/4.0/).

Indexing: Plant Science Today is covered by Scopus, Web of Science, BIOSIS Previews, ESCI, CAS, AGRIS, CABI, Google Scholar, etc. Full list at http://www.plantsciencetoday.online

\section{Introduction}

Microalgae are unicellular photosynthetic eukaryotes occupying diverse range of habitats including different environmental and geographical regions. Microalgae possess diverse applications including biofuel production, bioremediation, utilization as biofertilizers and animal feed, bioplastic synthesis, waste water treatment, synthesis of compounds with industrial/pharmaceutical applications including pigments, anti-aging compounds $(1,2)$. Algal proteins and polysaccharides are of industrial and nutritional importance. The ability to convert 
solar energy to lipid renders microalgae as the most appropriate and potential alternate source of energy. Besides this, their inherent ability to produce oxygen and bioremediation potential is crucial to maintain ecological balance for sustained environment $(3,4)$. The above mentioned applications become more pronounced owing to advantages associated with microalgae cultivation. Ability to tolerate and survive in wide range of environmental conditions, minimal nutritional requirement and rapid growth rate, efficient $\mathrm{CO}_{2}$ fixation makes cultivation of algae convenient and efficient. However, there are also certain factors which check or restrict algae growth. Presence of toxins, contamination and competitive microbes are primary concern during cultivation of algae. Studies are required to optimize large scale commercial cultivation practices alongwith optimization of cultivation conditions, screening / production of potential / improved strains, convenient and effective harvesting methods, etc.

Microalgae species have inherent potential to convert atmospheric carbon dioxide $\left(\mathrm{CO}_{2}\right)$ into lipids. $(5,6)$. Biofuel production from algae species have been recognized as an effective alternate of energy source (7). However, biofuel production from algae species encounters economical challenges in terms of biofuel production on commercial scale. Several methods including hydrothermal liquefaction, pyrolysis, gasification and direct combustion have been employed for biofuel production from different algal species $(8,9)$. Hydrothermal liquefaction (HTL) plants have been established by industries for the large-scale production of bio-crude oils (black viscous oils). Biocrude / bio-oil production focusing on the conversion of just a single microalgae through HTL technique is an effective procedure for the production of bio-oil or biocrude production from algae feedstock (10). Dalmas Neto et al (11) reported fast pyrolysis of algae to produce bio oil with high yield and low cost. Du et al (12) reported microwave assisted pyrolysis of Chlorella species to produce bio-oil. Du et al (12) and Kapoore et al 2018 (13) in their microwave assisted pyrolysis (MAP) of Chlorella spp. using a microwave oven resulted in the production of bio-oil yield of $28.6 \%$. GC-MS results of the bio-oil product showed the presence of aliphatic, aromatic hydrocarbons, phenols and other compounds which are the desirable compounds present in crude oils, petroleum and diesel. Production of biofuel from algae species generally employ utilization of thermo chemical processes, due to which a large proportion of proteins undergo decomposition. Kumar et al (14) depicted a process in which proteins present in algae were separated out (through hydrolysis) before algal biomass was subjected to biofuel production. The study also reported synthesis of polyurethane from algal proteins.
Studies conducted have revealed variation in optimum light is important for lipid synthesis in algal species $(5,15-17)$. Ever since the potential of algae species to produce biofuel has been recognized, there has been efforts to optimize methods to enhance lipid synthesis. Reduction in antenna size of algae species has been reported to enhance photosynthesis efficiency. Several methods including UV mutagenesis (18), Insertional mutagenesis (19), RNAi mediated gene silencing (20), Random mutagenesis (21), EMS induced mutagenesis $(22,23)$ have been reported to enhance / improve photosynthetic efficiency of algae species.

With ever increasing industrialization, industrial effluents are directly or indirectly released into the natural resources results in environmental pollution. Effluents released from various industries are enriched with potential toxic components such as heavy metals, enhanced phosphate, sulphate and nitrate content, ammonia, dissolved solids, phenolic compounds. Due to the presence of these potentially toxic components release of industrial effluent into water bodies have gained concern.

Minimizing or treatment of polluted soil or water has become utmost important for maintaining sustainability of environment. Bioremediation techniques are not only effective and efficient but environment-friendly approach for treatment of polluted soil. Besides plants (phytoremediation); bacteria and algae reportedly possess inherent potential for bioremediation (24).

Several studies have indicated application of algal species in the treatment of waste water from various sources (Table 1). Among different algal species, Chlorella vulgaris is the most commonly utilized algae for waste water treatment (25-30). Kumar et al (31) reported Chlorella minutissima and Scenedesmus spp. to effectively reduce COD, TDS and phosphate content of sewage water. Similarly, Lim et al (25), Kassas and Mohammed (32) and Ramirez et al (33) treated textile industry effluent with different algae. All three studies reported that Chlorella vulgaris effectively reduced COD contents of effluent. Lim et al (25) also reported 33\% reduction in the phosphate content with algal treatment. Kassas and Mohammed (31) simultaneously reported Scenedesmus spp., C. vulgaris and Muriellopsis spp. found equally effective for the treating textile industry effluent. Salgueiro et al (26) reported significant reduction in COD and removal of phosphate in domestic waste water treated with $C$. vulgaris. Acid mine drainage treated with Chlorella and Scenedesmus spp. resulted in the reduction of COD (34). Kumar et al (14) found that C. marina to possess potential to reduce phosphate, nitrate and ammonia from industrial effluent. Hammud et al (35) also reported Spirulina platensis to absorb copper ion from industrial waste water. The study also 
Table 1. Summary of potential of different algae species utilized for treatment of effluents

\begin{tabular}{|c|c|c|c|c|c|}
\hline $\begin{array}{l}\text { S. } \\
\text { No. }\end{array}$ & $\begin{array}{l}\text { Water sample from } \\
\text { various sources }\end{array}$ & $\begin{array}{l}\text { Algae species employed } \\
\text { for treatment }\end{array}$ & $\begin{array}{c}\text { Parameters } \\
\text { analyzed }\end{array}$ & Response / outcome & Author \\
\hline 1. & Sewage water & $\begin{array}{l}\text { Chlorella minutissima, } \\
\text { Scenedesmus spp. }\end{array}$ & $\begin{array}{l}\text { COD, TDS, } \\
\text { Phosphate } \\
\text { content }\end{array}$ & $\begin{array}{l}\text { Reduction in COD and TDS, } \\
\text { removal }(87.3 \%) \text { of Phosphate }\end{array}$ & (31) \\
\hline 2 & $\begin{array}{l}\text { Textile industrial } \\
\text { effluent }\end{array}$ & Chlorella vulgaris & $\begin{array}{l}\text { COD, Phosphate } \\
\text { content }\end{array}$ & $\begin{array}{l}\text { Reduction in COD, removal } \\
(33 \%) \text { of Phosphate }\end{array}$ & $(25)$ \\
\hline 3. & $\begin{array}{l}\text { Textile industrial } \\
\text { effluent }\end{array}$ & $\begin{array}{l}\text { Chlorella sp., Scenedesmus } \\
\text { sp., Muriellopsis sp. }\end{array}$ & COD & Reduction in COD & (33) \\
\hline 4. & $\begin{array}{l}\text { Textile industrial } \\
\text { effluent }\end{array}$ & Chlorella vulgaris & COD & Reduction up to $17.5 \%$ COD & (32) \\
\hline 5. & $\begin{array}{l}\text { Domestic, industrial, } \\
\text { agro waste water }\end{array}$ & Chlorella vulgaris & $\begin{array}{l}\text { COD, Phosphate } \\
\text { content }\end{array}$ & $\begin{array}{l}\text { Reduced COD Removal of } \\
\text { Phosphate (97\%) }\end{array}$ & (26) \\
\hline 6. & Acid mine drainage & $\begin{array}{l}\text { Chlorella, Scenedesmus } \\
\text { spp. }\end{array}$ & COD & Reduction in COD & $(34)$ \\
\hline 7. & $\begin{array}{l}\text { Electroplating, } \\
\text { tanning industrial } \\
\text { waste }\end{array}$ & Chlorella vulgaris & Chromium & $\begin{array}{l}\text { Adsorbed Chromium }(23.6 \mathrm{mg} / \\
\text { g) by algae }\end{array}$ & (27) \\
\hline 8. & $\begin{array}{l}\text { Olive mill waste } \\
\text { water }\end{array}$ & $\begin{array}{l}\text { Chlorella vulgaris, } \\
\text { Spirulina platensis }\end{array}$ & $\begin{array}{l}\text { COD, Phenolic } \\
\text { compounds }\end{array}$ & $\begin{array}{l}\text { Reduction in COD and } \\
\text { Phenolic compounds }\end{array}$ & (36) \\
\hline 9. & $\begin{array}{l}\text { Industrial effluent } \\
\text { with heavy metal }\end{array}$ & $\begin{array}{l}\text { Chlorella vulgaris, } \\
\text { Spirunera maxima }\end{array}$ & Zinc and Copper & $\begin{array}{l}\text { Reduced conc. of } \mathrm{Cu} \text { upto } 81 \% \\
\text { and } \mathrm{Zn} \text { up to } 94.1 \%\end{array}$ & (37) \\
\hline 10. & Industrial effluent & Chlorella marina & $\begin{array}{l}\text { Phosphorus, } \\
\text { Nitrate, Ammonia }\end{array}$ & $\begin{array}{l}\text { Reduced conc. of } \mathrm{PO}_{4}(88 \%), \\
\mathrm{NO}_{3}(64 \%), \mathrm{NH}_{3}(85 \%)\end{array}$ & (14) \\
\hline 11. & $\begin{array}{l}\text { Industrial waste } \\
\text { water }\end{array}$ & Spirulina platensis & Copper & $\begin{array}{l}\text { Adsorption of } \mathrm{Cu} \text { ions } \\
\text { increased with decrease in } \\
\text { algae biomass concentration }\end{array}$ & (35) \\
\hline 12. & Industrial effluent & Chlorella minutissima & $\begin{array}{l}\text { Phosphorus and } \\
\text { Nitrate }\end{array}$ & $\begin{array}{l}\text { Reduced conc. of } \mathrm{P}(4.47 \mathrm{ppm} \text { to } \\
1.15 \mathrm{ppm}) \text { and } \mathrm{N} \text { ( } 3.6 \mathrm{ppm} \text { to } \\
0.3 \mathrm{ppm})\end{array}$ & (39) \\
\hline 13. & Industrial effluent & $\begin{array}{l}\text { Chlorella vulgaris, } \\
\text { Scenedesmus quadricauda }\end{array}$ & $\begin{array}{l}\text { Phosohorus, } \\
\text { Nitrate, COD,BOD }\end{array}$ & $\begin{array}{l}\text { Removal efficiency } \\
\text { of P, N, BOD, COD increased }\end{array}$ & (29) \\
\hline 14. & Industrial effluent & $\begin{array}{l}\text { Scenedesmus obliquus, } \\
\text { Chlorella vulgaris, } \\
\text { Chlorella kessleri }\end{array}$ & $\begin{array}{l}\text { COD, Phosphate } \\
\text { content }\end{array}$ & $\begin{array}{l}\text { Reduction in COD, removal of } \\
\text { phosphate } 22 \%-62 \%\end{array}$ & $(40)$ \\
\hline 15. & $\begin{array}{l}\text { Industrial effluent, } \\
\text { sewage water }\end{array}$ & $\begin{array}{l}\text { Chlorella vulgaris, } \\
\text { Scenedesmus dimorphus }\end{array}$ & COD, TDS & Reduction in COD \& TDS & (41) \\
\hline 16. & Industrial effluent & Chlorella vulgaris & COD, TDS & Reduction in COD \& TDS & $(28)$ \\
\hline 17. & $\begin{array}{l}\text { Sewage and sea well } \\
\text { samples }\end{array}$ & $\begin{array}{l}\text { Chlorella vulgaris, } \\
\text { Chlorella salina }\end{array}$ & $\begin{array}{l}\text { COD, TDS, } \\
\text { Phosphate } \\
\text { content }\end{array}$ & $\begin{array}{l}\text { Reduction in COD \& TDS, } \\
\text { removal of phosphate }\end{array}$ & (30) \\
\hline
\end{tabular}

reported increased absorption of copper ions with decrease in concentration of algal biomass.

C. vulgaris and $C$. salina have also been reported to reduce TDS, COD and phosphate content from sewage and sea water samples (30). Several other studies have also reported potential of C. vulgaris, S. dimorphus, S. quadricauda, S. obliqus, C. kessleri to reduce COD, TDS and phosphate content of industrial effluent (28-30, 40, 41). Waste water obtained from olive mills potentially possesses high COD along with phenolic compounds. Ismail et al (36) utilized Chlorella vulgaris and Spirulina platensis to treat waste water obtained from olive mill and achieved reduction in COD and phenolic compounds.

One of the major concern associated with release of industrial effluent into environment (soil, water) is presence of heavy metals. Jyoti and Awasthi (27) reported Chlorella vulgaris to absorb chromium from waste water obtained from electroplating and tanning industry. Chan et al (37) also reported $C$. vulgaris and Spirulina maxima to reduce the concentration of zinc and copper in industrial effluent containing heavy metals. Algae have the potential for biosorption/neutralization of heavy metals present in the industrial effluents (38). Microalgae are useful in biomonitoring and restoring the aquatic ecosystems, which make it easier to extract and degrade the various organic and inorganic pollutants (24).

Algal species exhibit antimicrobial, antioxidant activity, anti-inflammatory, hypolipidemic, antihelmenthic, anticancer, antiprotozoal (42) and pharmacological properties (Table 2). Hoseini et al (43) reported antibacterial and antiviral potential of Sprirulina platensis. Nicoletti (44) reported antibacterial activity of $S$. platensis and Chlorella. Antioxidant activity by $C$. closterium is also on record (45). Priyadarshani and Ratu (46) demonstrated antimicrobial and 
Table 2. Biological activities of algae species

\begin{tabular}{cllc}
\hline Sl No. & Microalgae species & Medicinal uses & Author \\
\hline 1 & Spirulina platensis & Antibacterial, antiviral & $43)$ \\
\hline 2 & Spirulina platensis and Chlorella & Antibacterial, dietary supplement & $(44)$ \\
\hline 3 & Chlorella closterium & Antioxidant & $(45)$ \\
\hline 4 & $\begin{array}{l}\text { Isochrysis, Chaetoceros, Chlorella, } \\
\text { Arthrospira, Dunaliella }\end{array}$ & Antimicrobial, Antifungal & $46)$ \\
\hline 5 & Phaeocystis pouchetii & Antibiotic production & $(47)$ \\
\hline 6 & $\begin{array}{l}\text { Scenedesmus almeriensis, } \\
\text { Chlorella protothecoides }\end{array}$ & Reduce risk of retina damage by blue-light & $(50)$ \\
\hline 7 & Arthrospira & Antioxidant & $(51)$ \\
\hline 8 & Phaeocystis pouchetii & Antibiotic production & $(48)$ \\
\hline 9 & Spirulina platensis & Antioxidant, dietary supplement & $(52)$ \\
\hline 10 & Chlorella sorokiniana & Lowers the risk of premature death & $(49)$ \\
\hline
\end{tabular}

antifungal activity of Isochrysis, Chaetoceros, Chlorella, Arthrospira and Drenaniella. Mostafa (47) and Sigmani et al (48) stated that Phaeocystis pouchetii produces antibiotic with potential antimicrobial action. Sathashivam et al (49) observed that, Chlorella sorokiniana lowers the risk of premature death. Scenedesmus almeriensis and Chlorella protothecoides are capable to reduce risk of retina damage caused by blue light (50). Arthrospira (51) and S. platensis (55) possess antioxidant potential.

Synthesis of bioplastics from algal polymers successfully serves as a field of growing interest for researchers. Proteins obtained from different sources have been utilized for synthesis of plastics. Wheat gluten, soy protein, peanut protein are most commonly utilized plant proteins whereas gelatin, keratin, collagen are animal proteins utilized for synthesis of plastics (53-55). However, utilization of plant material for production of plastic appears to be practically unfavourable since the same plant material can be better utilized in food industry, as animal fodder, etc. Hence, utilization of algae for synthesis of bioplastic appears to be an efficient and appropriate alternative. Utilization of algae proteins for synthesis of bioplastics has several advantages including high protein content with high algal biomass yield; comparatively cost effective cultivation in natural habitat makes algae species most suitable alternate for production of plastics (55). Zeller et al (56) revealed bioplastics synthesized from Spirulina and Chlorella species to be compatible with plastics synthesized from protein of plant or animal origin. Substantial technological development is required to make production of bioplastics from algae a cost effective process. There can be no debate that plastics of algae are environment friendly and biodegradable as compared to conventional plastics. Besides this increasing viability of algal bioplastics can prove to be an effective contribution to economic development. Commercialization of bioplastics will automatically aid in conservation of fossil resources.

\section{Conclusion}

Widespread distribution and application of algal species including production of biofuel, bioremediation potential, synthesis of phytocompounds with medicinal, pharmaceutical and other biological activities renders algae to be cultivated on commercial scale. Diverse application of algae becomes more pronounced owing to their minimal growth requirement. Studies are required to optimize cultivation protocol for mass propagation of algae on large scale. Along with development of efficient cultivation protocol efforts are required to genetically modify / improve existing strains / species followed by selection of high yielding varieties. Practical application is required while utilizing algae for various purposes. Separation of proteins from algae species before extraction of oil provides an alternate to synthesize bio polymers since algal proteins are degraded during thermal/chemical processes employed during extraction of biofuel. In the present scenario, algal species stands out to be most potential bioresource for the treatment of polluted water simultaneously being an extremely effective alternate source of energy along with medicinal importance of many algal species.

\section{Authors' contribution}

NS and AS contributed towards design and prepared the initial draft of the manuscript. FL, V and RS have worked on acquisition, collection, compilation of literature for the present review. NS and RS have revised the manuscript after review. All authors read and approved the final manuscript. 


\section{References}

1. Sporaore P, Joannis CC, Duran E, Isambert A. Commercial applications of microalgae. Journal of Bioscience and Bioengineering 2006; 101:87-96. https:// doi.org/10.1263/jbb.101.87

2. Del CA, García GM, Guerrero M G. Outdoor cultivation of microalgae for carotenoid production: current state and perspectives. Applied Microbiol Biotechnol. 2007; 74:1163-74. https://doi.org/10.1007/s00253-007-0844-9

3. Gordon and Polle. Ultrahigh bioproductivity from algae. Applied Microbiol. Biotechnol. 2007; 76: 969-75. https://doi.org/10.1007/s00253-007-1102-x

4. Carvalno AA., Silva SO, Jose MB, Malcat XF. Light requirements in microalgal photobioreactors: an overview of biophotonic aspects. Appl. Microbio. Biotechnol. 2011; 2 (89):1275-88 https://doi.org/10.1007/s00253-010-3047-8

5. Ibrahim M, Salman M, Kamal S, Aneeza R, Sajid R, Akash H. Production and Processing of Algal Biomass. Algae Based Polymers, Blends, and Composites. Chemistry, Biotechnology and Materials Science. 2017; 155-271. https://doi.org/10.1016/B978-0-12-812360-7.00006-9

6. Ghosh A. An approach for phycoremediation of different wastewaters and biodiesel production using microalgae. Environ. Sci. Pollut. Int. 2018; 25(19):18673-81. https://doi.org/10.1007/s11356-018-1967-5

7. Ghosh SK, Tale MP, Kapadnis BP, Isolation and characterization of microalgae for biodiesel production from Nisargruna biogas plant effluent. Bioresource Tech. 2014; 169:328-58. https://doi.org/10.1016/j.biortech.2014.06.017

8. Kumar G, Shobana S,Chen WH, Bach QV, Kim SH, Atabani AE, Chang JS. A review of thermochemical conversion of microalgal biomass for biofuels: Chemistry and process. Green Chemistry. 2014; 19(1):44-87. https://doi.org/10.1039/C6GC01937D

9. Sharma PK, Saharia M, Srivastava R, Kumar S, Sahoo L. Tailoring microalgae for efficient biofuel production. Front. Mar Sci. 2018; 5(382):1-18. https://doi.org/10.3389/fmars.2018.00382

10. Barreiro DL, Wolter P, Ronsse F, Brilman W. Hydrothermal liquefaction (HTL) of microalgae for biofuel production: state of the art review and future prospects. Biomass bioener. 2013; 53(16):113-27. https:// doi.org/10.1016/j.biombioe.2012.12.029

11. Dalmas NCJ, Bittencourt S, Assmann R, Coraucci D, RicardoSoccol R, Chapter 4: Production of biofuels from algal biomass by fast pyrolysis. Biofuel Algae. 2014;143-53. $\quad$ https://doi.org/10.1016/B978-0-444-595584.00007-3

12. Du, Zhen-Yi \& Li, Yecong \& Wang, Xiaoquan \& Wan, Yiqin \& Chen, Qin \& Wang, Chenguang \& Lin, Xiangyang \& Liu, Yuhuan \& Chen, Paul \& Ruan, Roger. Microwave-assisted pyrolysis of microalgae for biofuel production. Bioresource technology. 2011; 102:489096. https://doi.org/10.1016/j.biortech.2011.01.055

13. Kapoore RV, Butler TO, Pandhal J, Vaidyanathan S. Microwave assisted extraction for microalgae:from biofuels to biorefinery. Biotech. crossmark. 2018;7(99):1-21. https://doi.org/10.3390/biology7010018

14. Kumar KS, Dahms HU, Won EJ, Lee JS, Shin KH, Microalgae-a promising tool for heavy metal remediation. Exotoxicology Env Safety. 2015; 113:32952. https://doi.org/10.1016/j.ecoenv.2014.12.019
15. Pal D, Khozin GI, Cohen Z, Boussiba S. The effect of light, salinity, and nitrogen availability on lipid production by Nannochloropsis sp. Appl Microbiol $\begin{array}{lll}\text { Biotechnol. 2011; } & \text { 90(4):1429-41. }\end{array}$ https://doi.org/10.1007/s00253-011-3170-1

16. Takeshita T, Ota S, Yamazaki T, Hirata A, Zachleder V, Kawano S. Starch and lipid accumulation in eight strains of six Chlorella species under comparatively high light intensity and aeration culture conditions. Bioresour Technol. 2014; 158:127-34. https://doi.org/10.1016/j.biortech.2014.01.135

17. Mandotra SK, Kumar P, Suseela MR, Nayaka, Ramteke PW. Evaluation of fatty acid profile and biodiesel properties of microalga Scenedesmus abundans under the influence of phosphorus, $\mathrm{pH}$ and light intensities. Bioresour Technol. 2016; 201:222-29. https://doi.org/10.1016/j.biortech.2015.11.042

18. Nakajima Y, Tsuzuki M, Ueda R. Improved productivity by reduction of the content of light-harvesting pigment in Chlamydomonas perigranulata. J. Appl. Phycol. 2001; 13:95-101. https://doi.org/10.1023/A:1011192832502

19. Polle JEW, Kanakagiri SD, Melis A. tla, a DNA insertional transformant of the green alga Chlamydomonas reinhardtii with a truncated lightharvesting chlorophyll antenna size . Planta. 2003; 217: 49-59.

20. Perrine Z, Negi S, Sayre RT. Optimization of photosynthetic light energy utilization by microalgae. Algal Research. 2012; 1: 134-42. https://doi.org/10.1016/j.algal.2012.07.002

21. Cazzaniga S, DallOsto L, Szaub J, Scibilia L, Ballottari M, Purton S, Bassi R. Domestication of the green alga Chlorella sorokiniana: reduction of antenna size improves light-use efficiency in a photobioreactor. Biotechnol Biofuels. 2014; 7(1):157. https://doi.org/10.1186/s13068-014-0157-z

22. Perin G, Bellan A, Segalla A, Meneghesso A, Alboresi A, Morosinotto T. Generation of random mutants to improve light-use efficiency of Nannochloropsis gaditana cultures for biofuel production. Biotechnology for Biofuels. 2015; 8:161. https://doi.org/10.1186/s13068-015-0337-5

23. Shin WS, Lee B, Jeong B, Chang YK, Kwon JH. Truncated light-harvesting chlorophyll antenna size in Chlorella vulgaris improves biomass productivity. J Appl Phycol. 2016; 28:3193-3202. https://doi.org/10.1007/ $\underline{\text { s10811-016-0874-8 }}$

24. Chekroun. The role of algae in bioremediation of organic pollutants. Int. Res. J. Pub. Env. Health. 2014; 1(2):19-32.

25. Lim SL,Wan LC, Siew MP. Use of Chlorella vulgaris for bioremediation of textile wastewater. Biosource Technology. 2010; 101: 7314-22 https://doi.org/10.1016/j.biortech.2010.04.092

26. Salgueiro JL, Perez L, Maceiras R, Sanchez A, Cancela A. Bioremediation of wastewater using Chlorella vulgaris microalgae: hosphorus and rganic matter. Int. J. Environ. Res. 2016; 10:465-70.

27. Jyoti J, Awasthi M. Bioremediation of wastewater Chromium through microalgae: a review. Int. J. Eng. Res \& Tech. 2014;3(6):1210-15.

28. Chalivendra S, Saikumar. Bioremediation of wastewater using microalgae (electronic thesis or dissertation). Retrieved from https://etd.ohiolink.edu/2014 
29. Kshirsagar AD. Bioremediation of wastewater by using microalgae: an experimental study. Int. J. Lifesc. Bt Pharm. res. 2013; 2:339-46.

30. El-Sheekh MM, Farghl A A, Galal HR, Bayoumi HS. Bioremediation of different types of polluted water using microalgae. Rend Fis Acc Lincei 2016; 27:401. https://doi.org/10.1007/s12210-015-0495-1

31. Kumar GS, Khan SA. Bioremediation of sewage water using selective algae for manure production. Int. J. Env. Eng. Man. 2013; 4(6):573-80.

32. Kassas, Mohammed. Bioremediation of the textile waste effluent by Chlorella vulgaris. The Egyp J Aqua Res 2014; 40(3):301-08. https://doi.org/10.1016/j.ejar.2014.08.003

33. Ramirez ME, Velez L, Rendon, Alzate E. Potential of microalgae in the bioremediation of water with chloride content. Brazilian J. Biology. 2017; 78:1-5. https://doi.org/10.1590/1519-6984.169372

34. Bwapwa J, Jayeola A, Chetty R. Bioremediation of acid mine drainage using algae strains: A review. S. African J. Chem. Engineering. 2017; 24:62-70. https://doi.org/10.1016/j.sajce.2017.06.005

35. Hammud HH, Ali El-S, Essam K, El-Sayed M. Adsorption studies of Lead by Enteromorpha algae and its silicates bonded material.Advances in chemistry. 2014; Artcle ID 205459,1-11, http://dx.doi.org/ $\underline{10.1155 / 2014 / 205459}$

36. Ismail, Azza AM, Abd El-All, Han AM. Biological influence of some microorganisms on olive mill waste water. Egypt J.Agric.Res. 2013; 91:1-11.

37. Chan A, Hamidreza S, McBean. Heavy metal removal (copper and zinc)in secondary effluents from waste water treatment plants by microalgae.ACS chemistry sus. Chem. Engg. 2014; 2:130-37. https://doi.org/10.1021/sc400289z

38. Zeraatkar AK, Ahmadzadeh H, Talebi AF, Moheimani NR, McHenry MP. Potential use of algae for heavy metal bioremediation, a critical review. J.Env.Man. 2016; https://doi.org/10.1016/j.jenvman.2016.06.059

181:817-37.

39. Sharma, Khan. Bioremediation of sewage wastewater using selective algae for manure production. Int. J. Env. Eng Manag. 2013; 4:573-80.

40. Delrue F, Pablo DAD, Sing SF, Fleury G, Sassi.JF. The environmental biorefinery: using microalgae to remediate wastewater, a win-win paradigm. Energies. 2015;9 (132):1-19. https://doi.org/10.3390/en9030132

41. Prabha Y, Soni SK, Sharmita G, Sonal. Potential of Algae in bioremediation of Wastewater: Current Research. Int. J. Curr. Microbial. App. Sci.2016; 5:693700. https://doi.org/10.20546/ijcmas.2016.502.076

42. Shahid A, Knan AZ, Liu T, Malik S, Afzal I, Mehmood MA. Algae-based biologically active compounds. Algae based polymers, blends, and composites. Chem biotech materials Sci. 2017; 273-99. https://doi.org/10.1016/B9780-12-812360-7.00007-0
43. Hosseini SM, Khosravi-Darani K, Mozafari MR. Nutritional and Medical Applications of Spirulina microalgae Mini-review. Med. Chem. 2013; 13:1231-37. https://doi.org/10.2174/1389557511313080009

44. Nicoletti M. Microalgae Nutraceuticals. Foods. 2016; 5(3):1-13. https://doi.org/10.3390/foods5030054

45. Sathasivam R, Radhakrishnan R, Hashem A, Allah E. Microalgae metabolites: A rich source for food and medicine. Saudi J. Bio Sci. 2017; 26:709-22. https://doi.org/10.1016/j.sjbs.2017.11.003

46. Priyadarshni, Rath B. Commercial and industrial applications of microalgae. A review. J Algal Biomass Utln. 2012; 3(4):89-100.

47. Mostafa SM Chapter 12: Microalgal Biotechnology. Plant Sci. 2012; 275-314.

48. Sigamani S, Natarajan H. A review on potential biotechnological applications of microalgae. J. App. Pharma. $\quad$ Sci. 2016; 6(8): 179-84 https://doi.org/10.7324/JAPS.2016.60829

49. Yamaguchi K. Recent advances in microalgal bioscience in Japan, with special reference to utilization of biomass and metabolites: a review. Appl Phycol 1996; 8(6): 487-502. https://doi.org/10.1007/BF02186327

50. Bhalamurugan GL, Valerie O Mark L. Valuable bioproducts obtained from microalgal biomass and their commercial applications. A review: Environ. Eng. Res. 2018; 23(3):229-41. https://doi.org/10.4491/eer.2017.220

51. Wells ML, Potin P, Craigie JS, Raven JA, Merchant SS, Helliwell KE, Smith AG, Camire ME, Brawley SH. Algae as nutritional and functional food sources: revisiting J. Appl. Phycol. 2016; 29(2):949-82. https://doi.org/10.1007/s10811-016-0974-5

52. Morais MG, Stillings C, Wendorff J. Biofunctionalized Nanofibres using Arthrospira (Spirulina) Biomass and Biopolymer. Biomed. Res. Int. 2015; 1-8. http://dx.doi.org/10.1155/2015/967814

53. Swain SN, Biswal SM, Nanda PK, Nayak PL. Biodegradable soy-based plastics: opportunities and challenges. J. Polym. Environ. 2004; 12 (1): 35-42. https://doi.org/10.1023/B:JOOE.0000003126.14448.04

54. Mekonnen T, Mussone P, Khalil H, Bressler D. Progress in bio-based plastics and plasticizing modifications. J. Mater. Chem. A, 2013; 1:13379-98. https://doi.org/10.1039/c3ta12555f

55. Rajendran N, Sharanya Puppala S, Raj SM, Angeeleena $\mathrm{RB}$, Rajam C. Seaweeds can be a new source for bioplastics. J. Pharm. Res. 2012; 5 (3): 1476-79.

56. Zeller MA, Hunt R, Jones A, Sharma S. Bioplastics and their thermoplastic blends from Spirulina and Chlorella microalgae. J. Appl. Polym. Sci. 2013; 130, 3263-75. https://doi.org/10.1002/app.39559 